\title{
Gross brain morphology of Rhamdia quelen (Quoy \& Gaimard 1824) (Ostariophysi: Siluriformes: Heptapteridae)
}

\author{
Vitor Pimenta Abrahão ${ }^{1,2,3}$, Fábio Müller dos Reis de Salles Pupo ${ }^{1,4}$ \& Oscar Akio Shibatta ${ }^{2,5}$ \\ 1 Universidade de São Paulo (USP), Museu de Zoologia (MZUSP). São Paulo, SP, Brasil. \\ ${ }^{2}$ Universidade Estadual de Londrina (UEL), Departamento de Biologia Animal e Vegetal (BAV), Centro de Ciências Biológicas (CCB). \\ Londrina, PR, Brasil. \\ ${ }^{3}$ ORCID: 0000-0002-4413-2334. E-mail: vitorabraha032@gmail.com \\ ${ }^{4}$ ORCID: 0000-0002-2757-0295. E-mail: fmpupo@gmail.com \\ 5 ORCID: 0000-0003-2883-5934. E-mail: oscar.shibatta@gmail.com
}

\begin{abstract}
The brain gross morphology of Rhamdia quelen is described and compared with seven species of six genera of Heptapteridae. Interspecific variation in shape, size, and position of brain subdivisions was observed in all examined species. The posterior position of the hypophysis on the hypothalamus and presence of a lateral subdivision on the lobus facialis are shared by all examined heptapterids. Rhamdia quelen and Pimelodella gracilis, currently considered closely related within the family Heptapteridae, exhibit the anterior and posterior area of the telencephalon with equivalent widths, and the lateral line lobe reaching the anterior area of the lobus vagi. Members of the so called Nemuroglanis sub-clade (Cetopsorhamdia iheringi, Heptapterus mustelinus, Imparfinis mirini, and Phenacorhamdia tenebrosa) share the lobus vagi proportional smaller than the lobus facialis; the lateral line lobe reaching the half length of the lobus facialis; the tectum mesencephali in contact with the telencephalon, and thinner anterior area of the telencephalon. The results reveal several features that are phylogenetically informative among the heptapterids examined, and corroborate previous hypotheses based on other non-neural anatomical characters.
\end{abstract}

Key-Words. Central nervous system; Anatomy; Catfish; Neotropical region.

\section{INTRODUCTION}

Siluriformes is a diverse order of the Otophysi, widely distributed across the globe, mainly throughout the tropical regions. It presents a high morphological diversity, especially when compared to its close relatives, the Characiformes and Cypriniformes (Rosen \& Greenwood, 1970; Fink \& Fink, 1981; Howes, 1983; Ferraris Jr., 2007). However, despite this wide morphological disparity, studies on the brains of Neotropical catfishes have been largely neglected; as opposed to what happens with the North American ictalurids where its neuroanatomy is relatively better understood (Herrick \& Herrick, 1891; Atema, 1971; Lundberg, 1982; Tong \& Finger, 1983; Meek \& Nieuwenhuys, 1998). To date, there are few studies published on gross brain morphology of neotropical catfishes (e.g., Rosa et al., 2014 on Otothyris; Abrahão \& Shibatta, 2015 on Pseudopimelodus bufonius; Angulo \& Langeani, 2017 on Rineloricaria heteroptera; and Abrahão et al., 2018 on Pseudopimelodidae).

Among Siluriformes, Heptapteridae currently includes 218 valid species of small to me- dium-sized catfishes distributed in 24 genera (Eschmeyer \& Fong, 2018). They live among rocks and logs on river bottoms, associated to marginal vegetation or buried in sand (Bockmann \& Guazelli, 2003). The family was first proposed a monophyletic group within the Pimelodidae by Lundberg \& McDade (1986), and later corroborated by Ferraris Jr. (1988) and Lundberg et al. (1991), in which members of the Heptapteridae were included in the subfamily Rhamdiinae. Recent studies regarding the phylogenetic relationships on catfishes, based on molecular analysis, have proposed that the Heptapteridae is more related to a clade composed by the Pimelodidae, Pseudopimelodidae and Conorhynchos (Hardman, 2005; Sullivan et al., 2006; Sullivan et al., 2013). Bockmann (1998), on the other hand, was the first to propose a more encompassing phylogenetic relationship of the Heptapteridae, recognizing some synapomorphies, based on the external morphology and osteology, for several species groups.

In the Heptapteridae, the genus Rhamdia Bleeker 1858 can be diagnosed by a unique combination of nine characters (Silfvergrip, 1996), and nowadays includes 27 species (Eschmeyer 


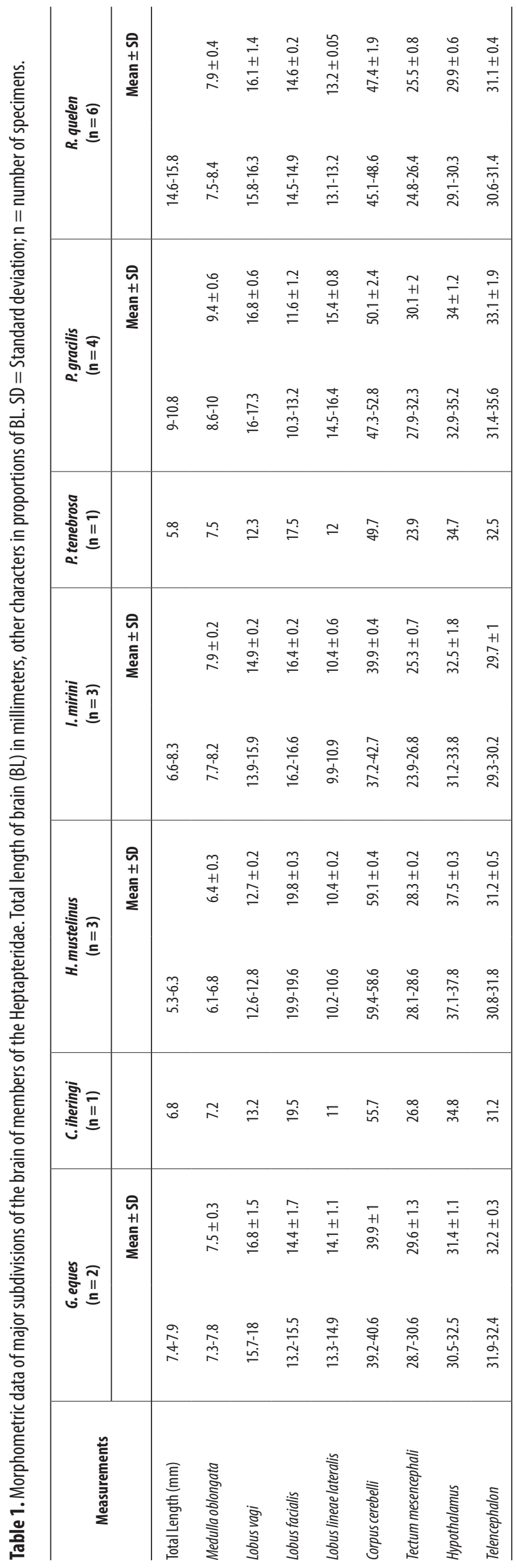

\& Fong, 2018). Rhamdia quelen (Quoy \& Gaimard, 1824) is widely distributed from northern Mexico to southern South America, in both cis- and trans-Andean watersheds, and is one of the most interesting taxa in the genus due to sympatric and even syntopic occurrence with other congeners. Although the ubiquitous distribution throughout the neotropical region, the complicated taxonomic history and the vast list of synonymies, the species can be distinguished by a set of 12 character states (Silfvergrip, 1996). However, there is disagreement as to the validity of these characters that can embrace several different morphotypes under a single name (Angrizani \& Malabarba, 2018).

The fish brains exhibit a great plasticity that can also be found within specialized organs that are strongly correlated to environmental changes and behavioral adaptations in niches (Kleerekoper, 1969; Ito et al., 2007), demonstrating that similar environments often lead to similar solutions (Kotrschal et al., 1998). This results in some divergent morphological patterns found among phylogenetic distant taxa (Kotrschal \& Palzenberger, 1992; Eastman \& Lannoo, 1995; van Staaden et al., 1995; Ito et al., 2007). However, some recent works on neotropical fish brains in a systematic framework show evidences that several sub-units have their shape due to shared evolutionary history rather than ecology (GonzalezVoyer \& Kolm, 2010; Pupo, 2011; Abrahão, 2013; Pereira, 2014; Pupo, 2015; Abrahão et al., 2018).

Few studies on morphological diversity within the Heptapteridae have been published to date (e.g., Lundberg \& McDade, 1986; Silfvergrip, 1996; Bockmann \& Miquelarena, 2008; Slobodian \& Bockmann, 2013), and the literature is even scarce when concerning the brain gross morphology of this group. Herein, the brain gross morphology and major cranial nerves of the $R$. quelen are described. Anatomical including seven other representatives of the family Heptapteridae are also made. Finally, intrafamiliar characters evolution is discussed.

\section{MATERIAL AND METHODS}

Brain gross morphology was obtained from six dissected specimens of $R$. quelen (187.4-222.3 mm SL) and compared to seven other species of the Heptapteridae. Dissections were performed following Abrahão \& Pupo (2014) and Abrahão \& Shibatta (2015). A digital camera attached to a stereoscopic microscope was used to capture images of the brain topography. Measurements of the major brain topographic units were taken on digital images, using the software Axio Vision Rel v.4.8 (Carl Zeiss Axio Vision Product Suite), and are expressed and presented as proportions of the total brain length (BL), see Table 1. Total brain length was measured from the rostral portion of the telencephalon to the most caudal portion of the lobus vagi (modified from Lannoo \& Eastman, 2000). Only the lobus inferior hypothalami was measured in the diencephalon, because this region has visible topography and with well-defined boundaries. Neuroanatomy nomenclature follows Meek \& Nieuwenhuys (1998) and 
Butler \& Hodos (2005). Osteological nomenclature follows Silfvergrip (1996), Bockmann (1998), and Arratia et al. (2003). Brains were kept in 4\% formalin buffered with $\mathrm{CaCO}_{3}$, after removal from the neurocranium. All specimens were preserved in $70 \%$ ethanol after fixation in $4 \%$ formalin. The software $R$ ( $R$ Core Team, 2017) was used to perform the statistical analysis.

\section{Material examined}

All specimens are deposited at the Museu de Zoologia da Universidade Estadual de Londrina (MZUEL) and the Museu de Zoologia da Universidade de São Paulo (MZUSP). Specimens are designated as ALC (alcohol), SK (dry skeleton), or C\&S [cleared and double stained according to Dingerkus \& Uhler (1977)]. Cetopsorhamdia iheringi Schubart \& Gomes, 1959. MZUEL 2260 (2 ALC: 50.8-51.9 mm SL). Goeldiella eques (Müller \& Troschel, 1849). MZUEL 7417 (2 ALC: 57.1-64.9 mm SL). Heptapterus mustelinus (Valenciennes, 1835). MZUEL 5074 (3 ALC: 66.1-63.4 mm SL). Imparfinis mirini Haseman, 1911. MZUEL 5765 (1 ALC: 83.2 mm SL). MZUEL 4028 (2 ALC: 50.6-51.6 mm SL). Phenacorhamdia tenebrosa (Schubart, 1964). MZUEL 2706 (2 ALC: 65.1-66.1 mm SL). Pimelodella gracilis (Valenciennes, 1835). MZUEL 1574 (4 ALC: 117.6-132.2 mm SL). Rhamdia quelen. MZUEL 6036 (6 ALC: 187.4-222.3 mm SL); MZUEL 7418 (1 C\&S: 61 mm SL); MZUEL 7455 (1 SK: 163.27 mm SL).

Comparative material: Batrochoglanis raninus (Valenciennes 1840). MZUEL 6035 (1 ALC: 76.7 mm SL). MZUSP 23407 (2 ALC: 51.4-76.6 mm SL). Cephalosilurus fowleri Haseman 1911. MZUEL 6040 (1 ALC: 275 mm SL). Conorhynchos conirostris (Valenciennes 1840). MZUEL 6673 (1 ALC: 390.0 mm SL). Diplomystes mesembrinus (Ringuelet 1982). MZUSP 62595 (1 ALC: 79.0 mm SL). Ictalurus punctatus (Rafinesque 1818). MZUEL 6671 (3 ALC: 78.87-82.34 mm SL). Lophiosilurus alexandri Steindachner 1876. MZUEL 5377 (1 ALC: 53.7 mm SL). MZUSP 96276 (1 ALC: 73.1 mm SL). Microglanis cottoides (Boulenger 1891). MZUEL 6033 (3 ALC: 40.1-48.8 mm SL). Phreatobius sanguijuela Fernández, Saucedo, CarvajalVallejos \& Schaefer 2007. MZUEL 6486 (1 ALC: 39.0 mm SL). Pimelodus maculatus Lacepède 1803. MZUEL 1343 (3 ALC: 181.7-243.2 mm SL). Pseudopimelodus mangurus (Valenciennes 1835). MZUEL 2795 (2 ALC: 138.9-175.4 mm SL). Steindachneridion parahybae (Steindachner 1877). MZUEL 5231 (1 ALC: 262.4 mm SL). Zungaro zungaro (Humboldt 1821). MZUEL 6044 (1 ALC: 158.8 mm SL). MZUEL 6049 (1 ALC: 181.4 mm SL).

\section{RESULTS}

Measurements of the major brain subdivisions of the species examined are presented in Table 1. The brain is completely located beneath the supraoccipital and frontal bones, and above the parasphenoid and prootic in species of Heptapteridae, with exception of the bulbus olfactorius and part of the anterior portion of the telencephalon (Fig. 1).

\section{Rhombencephalon}

In all species examined the medulla oblongata is located posterior to the efferent projections of the nervus vagus to the medulla spinalis and is positioned dorsal to the truncus cerebri. The anterior portion lies posterolateral to the lobus vagi, and is positioned above the parasphenoid-basioccipital suture, beneath the supraoccipital process (Fig. 1). The medulla oblongata is topographically composed of two ovoid-shaped structures contacting the medulla spinalis. The posterior portion of the medulla oblongata is slightly thinner than their counterparts (Fig. 2). In Rhamdia quelen (Fig. 2), Imparfinis mirini, and Phenacorhamdia tenebrosa (Fig. 3), the medulla oblongata does not possess a conspicuous bulge posterolateral to the lobus vagi. In Goeldiella eques, Cetopsorhamdia iheringi, Heptapterus mustelinus and Pimelodella gracilis, the medulla oblongata is slightly bulged posterolaterally (Fig. 3). The length of the medulla oblongata in relation to the $\mathrm{BL}$ is similar in R. quelen, G. eques and I. mirini, although significantly different from the other examined species (Table 1).

The lobus vagi is located at the dorsal portion of the rhombencephalon, positioned beneath the supraoccipital and supraoccipital process (Fig. 1). In dorsal view, these lobes lie immediately posterior and continuous to the lobus facialis and are anteromedially located to the medulla oblongata. In all species examined the lobus vagi is composed of two cylindrical, paired, V-shaped lobes, with anterior bulges. These lobes contact each other only in their posterior portions, forming an acute tip (Figs. 2 and 3). The lobus vagi is longer than the lobus facialis in $R$. quelen, $G$. eques and $P$. gracilis. In all remaining species examined the inverse was found. The lobus vagi length in relation to $B L$ is substantially smaller in $\mathrm{H}$. mustelinus (Fig. 3, Table 1). The presence of a conspicuous bulge on the anterior portion of lobus vagi is shared by all Heptapteridae species examined herein (Fig. 3).

The lobus facialis is located at the dorsal portion of the rhombencephalon, positioned beneath the supraoccipital process (Fig. 1). In dorsal view, it is posterior to the corpus cerebelli, anterior to the lobus vagi, and medially located in relation to the lateral line lobe. A small portion of the anterior area of the lobus facialis is positioned beneath the posterior area of the corpus cerebelli (Fig. 2). The lobes of the lobus facialis are bilaterally symmetrical and do not contact each other. In all species examined these lobes are longitudinally elongate, somewhat rectangular-shaped, but with rounded edges in dorsal view. The lobus facialis is continuous with the lobus vagi and the lateral line lobe, but not with the corpus cerebelli. There is a conspicuous bulge laterally positioned over to each lobe of the lobus facialis (Figs. 2 and 3). Except for H. mustelinus and $P$. gracilis, the proportional length of the lobus facialis is larger than the length of the lateral line lobe in all species examined (Table 1). The length of the lobus 
facialis in relation to $\mathrm{BL}$ is longer in $R$. quelen, $G$. eques and I. mirini, and shorter in H. mustelinus (Table 1).

The lateral line lobe is located at the dorsal portion of the rhombencephalon and is positioned beneath the supraoccipital (Fig. 1). It lies posterolateral to the eminentia granularis and the corpus cerebelli and is located laterally in relation to the lobus facialis. The lateral line lobe is formed by two conspicuous bulges, ovoid-shaped, with two subdivisions each one. The anterior bulge is located posterolaterally to the eminentia granularis and the corpus cerebelli, while the posterior bulge is positioned lateral to the lobus facialis. In all examined species the anterior bulge is more prominent than the posterior bulge (Figs. 2, 3 and 4). In R. quelen, G. eques and P. gracilis the lateral line lobe extends up to the anterior portion of the lobus vagi, whereas in all remaining species these lobes extend up to the half-length of the lobus facialis (Figs. 2 and 3). In all examined species, the proportional width of the lateral line lobe is larger than to the medulla oblongata and smaller than the length of the lobus vagi

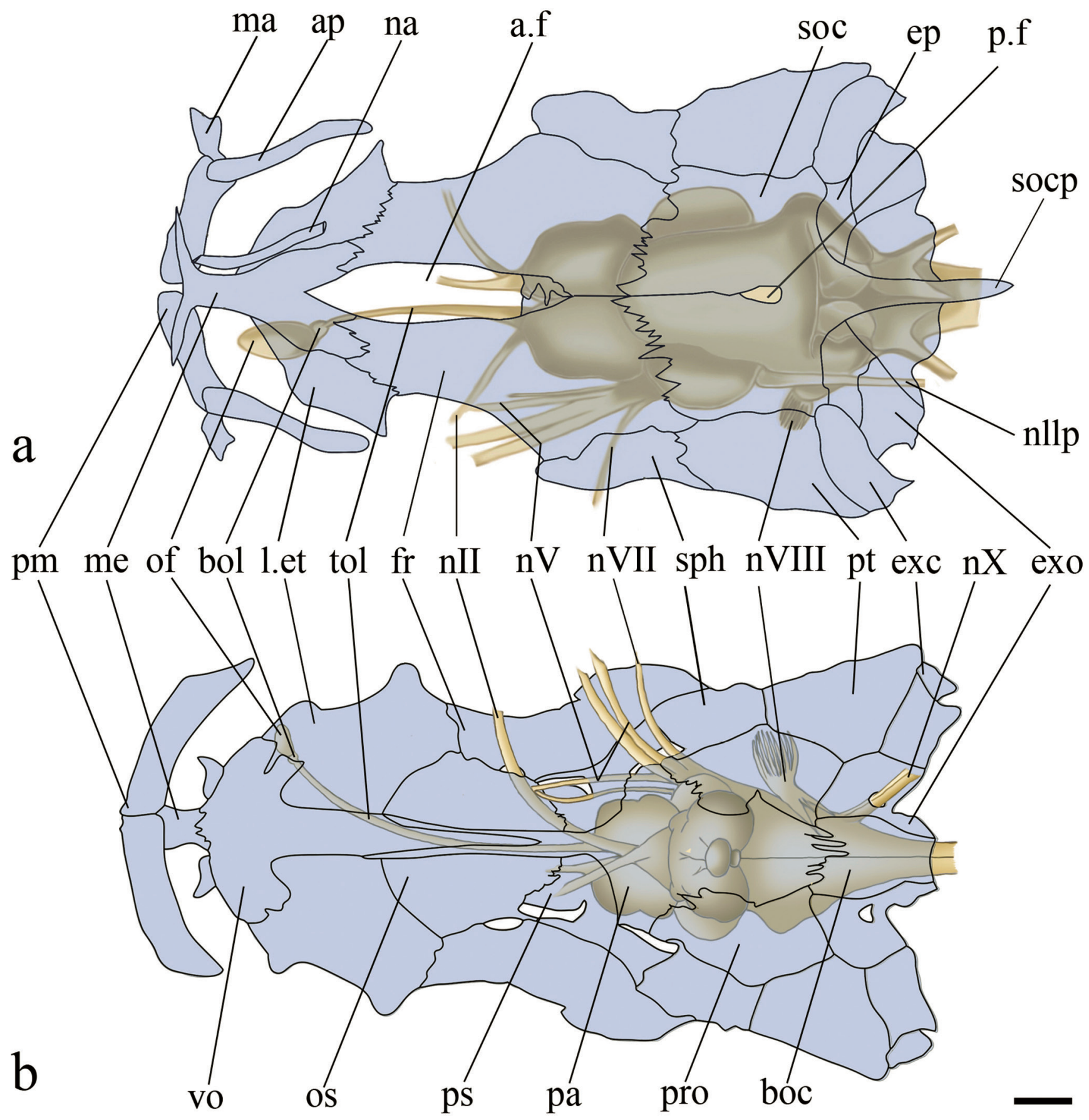

Figure 1. Camera lucida drawing of the brain and neurocranium of an adult specimen of Rhamdia quelen, MZUEL 7418, $64.03 \mathrm{~mm}$ SL, in dorsal (a) and ventral (b) views. a.f: anterior fontanel; ap: autopalatine; boc: basioccipital; bol: bulbus olfactorius; ep: epiotic; exc: extracapula; exo: exoccipital; fr: frontal; I.et: lateral ethmoid; ma: maxilla; me: mesethmoid; nll: nervus opticus; nV: nervus trigeminus; nVII: nervus facialis; nVIII: nervus octavus; nX: nervus vagus; na: nasal; nllp: nervus lineae lateralis posterior; of: olfactory organ; os: orbitosphenoid; pa: parasphenoid; p.f: posterior fontanel; p.m: premaxillary; pro: prootic; ps: pterosphenoid; pt: pterotic; soc: supraoccipital; socp: supraoccipital process; sph: sphenotic; tol: tractus olfactorius; vo: vomer. Scale bar $=1 \mathrm{~mm}$. 


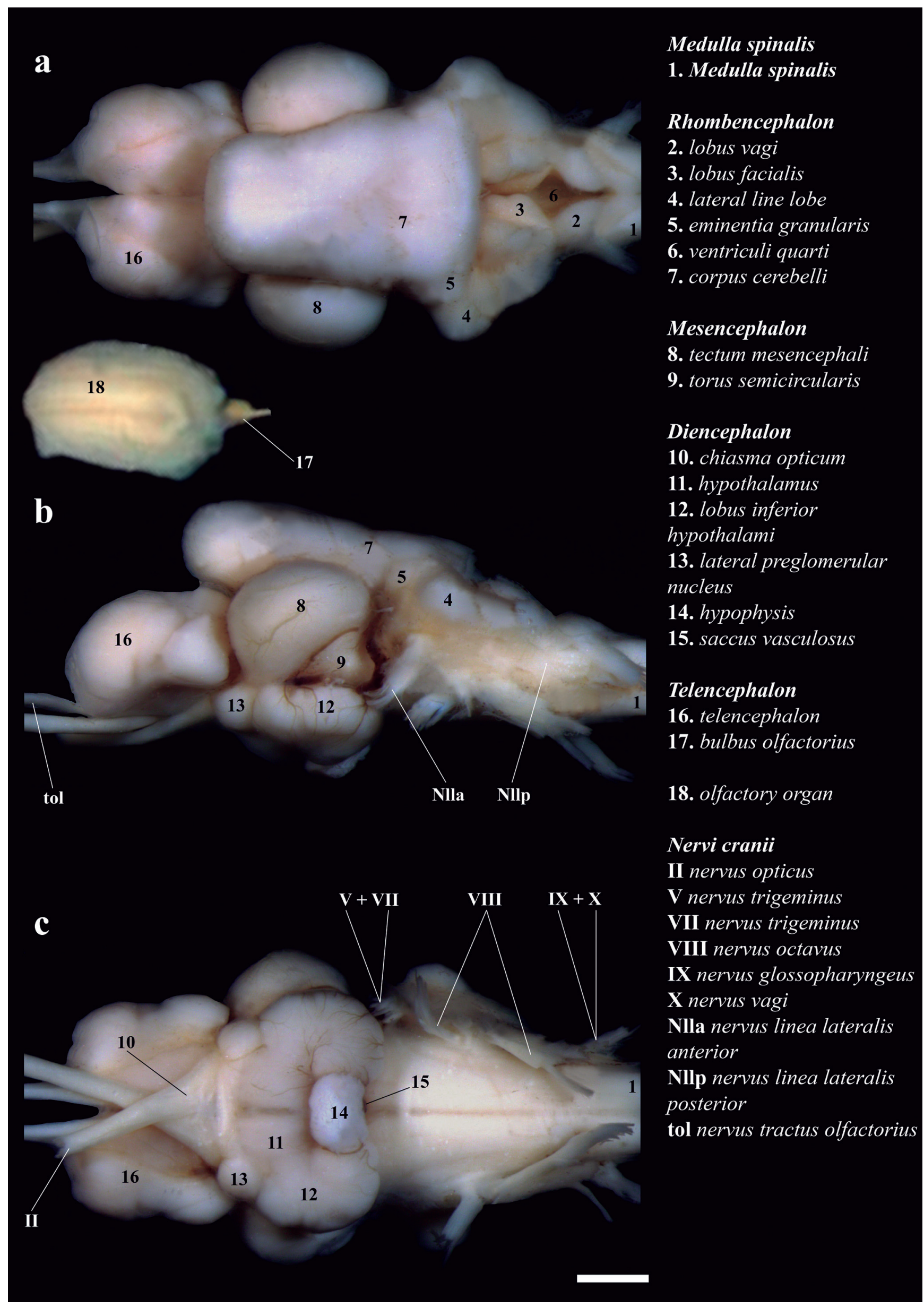

Figure 2. Brain of Rhamdia quelen, MZUEL 6036, $222.37 \mathrm{~mm} \mathrm{SL}$, in (a) dorsal, (b) lateral and (c) ventral views. Scale bar $=1 \mathrm{~mm}$. 
(Table 1). The width of the lateral line lobe relative to $B L$ is similar in $R$. quelen and G. eques. The width of this lobe is larger in P. gracilis, and smaller in H. mustelinus and I. mirini (Table 1).

The eminentia granularis is located at the dorsal region of the rhombencephalon, positioned beneath the supraoccipital bone (Fig. 1). In dorsal and lateral views, it is posterolateral to the posterior area of the corpus cerebelli, anterior to the lateral line lobe, and posterior to the tectum mesencephali. The lobes of the eminentia granularis are somewhat cylindrical in dorsal view, and ovalshapped with the posterior portion slightly smaller than the anterior one, in lateral view. The corpus cerebelli is located at the dorsal portion of the rhombencephalon, positioned beneath the supraoccipital (Fig. 1). This lobe is located immediately anterior to the lobus facialis, dorsal to the hypothalamus, and medial to the lobes of the tectum mesencephali. The anterior portion of this structure is dorsal to the posterior area of the telencephalon. The corpus cerebelli has a trapezoid shape, with the anterior region slightly smaller than the posterior one. The dorsal margin in lateral view and the lateral margin in dorsal view are straight, without conspicuous undulations
(Fig. 2). In R. quelen and $P$. gracilis the anterior and posterior margins in dorsal view are also straight, whereas in $G$. eques the anterior portion is straight, and the posterior portion has two flaps (Fig. 3). In H. mustelinus, I. mirini, and $C$. iheringi the anterior portion of the corpus cerebelli is rounded, whereas the caudal portion is flap-shaped (Fig. 3). In P. tenebrosa the anterior portion is pointed and the posterior portion is flap-shaped (Fig. 3). The corpus cerebelli contacts the telencephalon in all examined species (Fig. 4). In all examined species the corpus cerebelli is the largest subdivision of the brain. The proportional length of the corpus cerebelli in relation to $\mathrm{BL}$ is longer in $H$. mustelinus, intermediate in $R$. quelen and $P$. gracilis, and shorter in G. eques and I. mirini (Table 1).

The efferent projections of the nervus glossopharyngeus and the nervus vagus emerge from the lateral wall of the rhombencephalon, approximately at half-length of the lobus vagi. These branches pass through the braincase by a foramen in the exoccipital. The nervus octavus, and nervus linea lateralis posterior emerge from the ventrolateral face of the rhombencephalon, at approximately the mid-point of the lateral line lobe. The nervus facialis and nervus trigeminus emerge from the ventrolateral wall

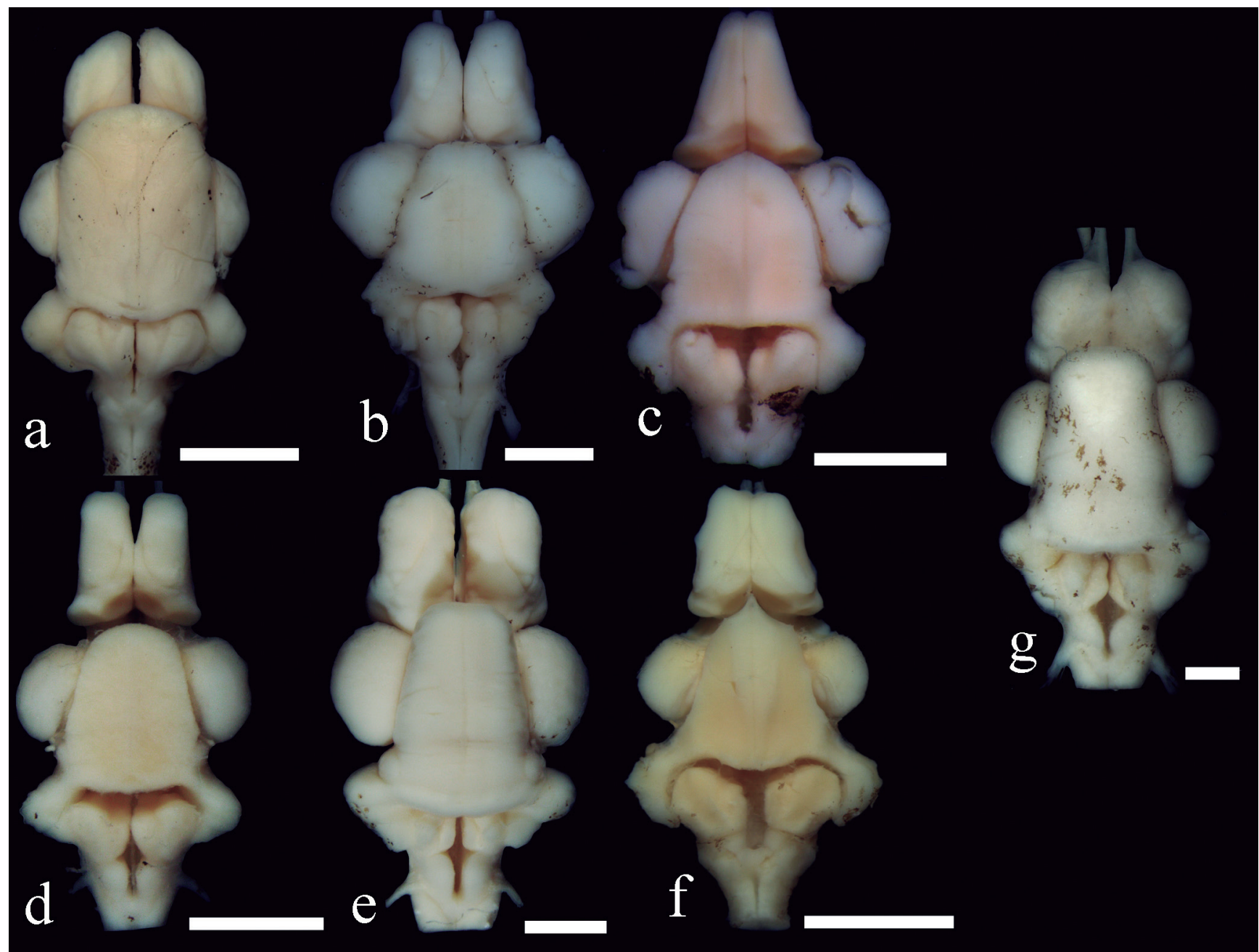

Figure 3. Brain of species of Heptapteridae in dorsal view. (a) Cetopsorhamdia iheringi, MZUEL 2260; (b) Goeldiella eques, MZUEL 7417; (c) Heptapterus mustelinus, MZUEL 5074; (d) Imparfinis mirini, MZUEL 4028; (e) Pimelodella gracilis, MZUEL 1574; (f) Phenacorhamdia tenebrosa, MZUEL 2706; (g) Rhamdia quelen, MZUEL 6036. Scale bar $=1 \mathrm{~mm}$. 
of the rhombencephalon, anterior to the nervus octavus, exiting the efferent projections of the braincase through a foramen on the suture between the parasphenoid, prootic and pterosphenoid. The anterior branches of the nervus facialis and nervus trigeminus exit their efferent projections from the braincase through a single foramen between the pterosphenoid, frontal and orbitosphenoid (Fig. 1).

\section{Truncus cerebri}

The truncus cerebri is located on the ventral surface of the brain; it is comprised by the rhombencephalon and the mesencephalon. It is positioned at the posterior portion of the mesencephalon to the anterior portion of the medulla spinalis (Fig. 2). Almost all cranial nerves exit their efferent projections from the truncus cerebri, except for the nervus olfactorius ( $\mathrm{nl}$ ) and the nervus opticus (nII). The cranial nerves that exit the truncus cerebri include: nervus oculomotorius (nIII), nervus trochlearis (nIV), nervus trigeminus (nV) nervus abducens (nVI), nervus facialis (nVII), nervus octavus (nVIII) nervus glossopharyngeus (nIX), nervus vagus ( $\mathrm{nX}$ ), nervus lineae lateralis anterior (nlla) and the nervus lineae lateralis posterior ( $\mathrm{nllp}$ ). Variations in the shape or proportional length of the truncus cerebri among the examined species were not found.

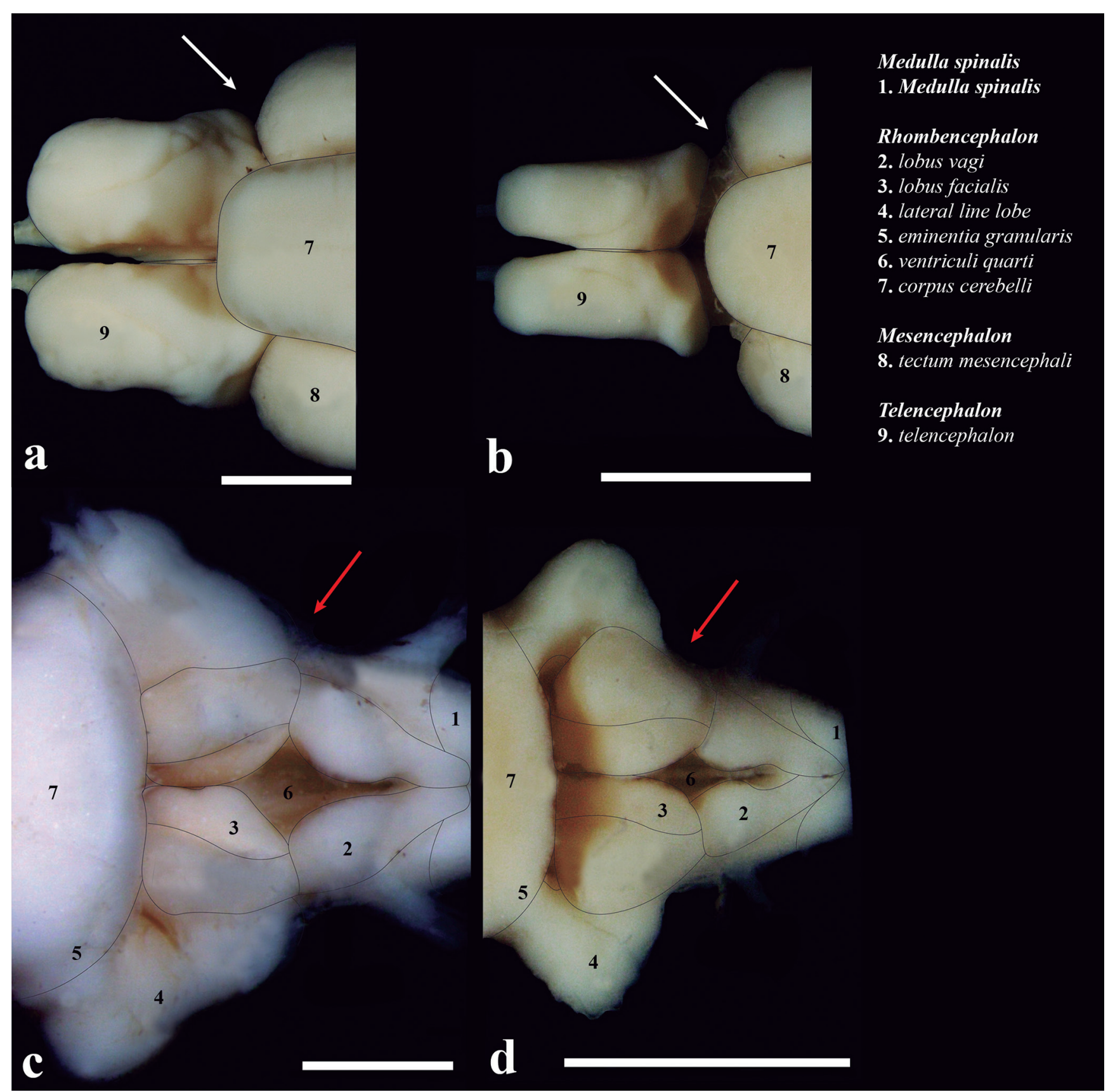

Figure 4. Details brain regions of species of Heptapteridae in dorsal view. (a) Pimelodella gracilis, MZUEL 1574; (b) Imparfinis mirini, MZUEL 4028; (c) Rhamdia quelen, MZUEL 6036; (d) Imparfinis mirini, MZUEL 4028. White arrows indicate the position of tectum mesencephali in relation to telencephalon. Red arrows indicate the position of lateral line lobe in relation to lobus vagi. Scale bar $=1 \mathrm{~mm}$. 


\section{Mesencephalon}

The tectum mesencephali is located at the dorsal portion of the tegmentum mesencephalic, lateral to the corpus cerebelli in dorsal view and posterior to the telencephalon in lateral view. The lobes of the tectum mesencephali are positioned beneath the supraoccipital and frontal bone (Fig. 1). This subdivision has two bilateral, almost spherical, lobes in dorsal and lateral views (Fig. 2). In $R$. quelen, G. eques and P. gracilis these lobes contact the corpus cerebelli and the telencephalon. In all remaining representatives, the tectum mesencephali contact only the corpus cerebelli (Fig. 3). In all specimens, the length of the tectum mesencephali is proportional shorter than the length of the corpus cerebelli, telencephalon, and the lobus inferior hypothalami (Table 1). The length of the tectum mesencephali in relation to $\mathrm{BL}$ is substantially shorter in I. mirini (Table 1).

The nervus opticus (nII) emerges from the tectum mesencephali on the mesencephalon, and its efferent projections exit in the region immediately anterior to the lobus inferior hypothalamic. These fibers contact each other and cross the midline of the brain at the region of the chiasma mesencephalic. The efferent projections of the nervus opticus exit the braincase through a foramen located between the frontal and orbitosphenoid, near the pterosphenoid (Fig. 1).

\section{Diencephalon}

The lobus inferior hypothalami is located at the ventral portion of the diencephalon, in a posterior region to the chiasma mesencephali, ventral to the truncus cerebri and the tectum mesencephalic, lateral to the hypothalamus in ventral view, and posterior to the telencephalon in lateral view (Fig. 2). The lobes of the lobus inferior hypothalamiare positioned above the parasphenoid and prootic (Fig. 1). The lobus inferior hypothalami is semicircular, with the anterior portion slightly smaller than the posterior portion. The hypophysis remains anchored posteriorly on the lobus hypothalamus and is located between the lobes of the lobus inferior hypothalami (Fig. 2). The hypothalamus is also located at the ventral portion of the diencephalon, medially and above the lobus inferior hypothalamic. The lobes of the hypothalamus are rounded. The proportional length of the lobus inferior hypothalami is shorter than the telencephalon only in R. quelen, G. eques and H. mustelinus (Table 1). The length of this subdivision in relation to $\mathrm{BL}$ is longer in $\mathrm{H}$. mustelinus (Table 1 ).

\section{Telencephalon}

In all examined specimens, the telencephalon is located anterior to the tectum mesencephali in lateral view, posterior to the bulbus olfactorius, and with the posterior area positioned beneath the corpus cerebelli in dorsal and lateral views (Fig. 2). The lobes of the telencephalon are positioned completely beneath the frontal (Fig. 1). In I. mirini the telencephalon does not contact the corpus cerebelli (Fig. 3). The telencephalon is longitudinally elon- gate, like a cylinder, with both the anterior and posterior margins rounded. In all examined species the anterior margin of the telencephalon is slightly smaller than the posterior one. In $R$. quelen and $P$. gracilis the anterior and posterior margins of these lobes have equivalent widths. In all remaining examined species the anterior portion is slight smaller than the posterior one (Fig. 3). There are no substantial differences in the proportional length of this subdivision among species examined (Table 1).

The bulbus olfactorius is stalked and is positioned at the anterior portion of the brain. This structure is located beneath the nasal, near to the articulation between the lateral ethmoid and the vomer (Fig. 1). The bulbus olfactorius is rounded, with equivalent widths of its anterior and posterior margins. It is connected to the olfactory epithelium via the nervus olfactorius, and to the telencephalon via the tractus olfactorius (Fig. 2). Length and shape variations of the bulbus olfactorius were not found. The olfactory epithelium is rounded, with the anterior margin slight smaller than the posterior one. It has a considerable amount of lamellae on each side, granting it a feather appearance (Fig. 2).

\section{DISCUSSION}

Morphometric and gross morphology variations were found on the brains of the examined species. No minor intraspecific variation and sexual dimorphism in brains were observed. These combinations of remarkable intergeneric and limited intraspecific variations suggest that characters derived from brain anatomy may be useful for phylogenetic inferences.

The brain gross morphology of $R$. quelen and other species of the Heptapteridae examined here share some features with other members of the Pimelodoidea, a clade corroborated by morphological (Lundberg et al., 1991; Bockmann, 1998; Bockmann \& Guazzelli 2003; Lundberg \& Littmann, 2003; Shibatta, 2003; Birindelli \& Shibatta, 2011) and molecular-based data (Hardman, 2005; Sullivan et al., 2006; Sullivan et al., 2013). These shared conditions and characters are: (1) the lobus vagi composed of two cylindrical, paired, and V-shaped lobes, and (2) the lateral line lobe composed of two conspicuous bulges, ovoid-shaped, with the anterior portion more prominent than the posterior one. Contrasting to Pimelodidae and Pseudopimelodidae, members of the Heptapteridae share the following putative synapomorphies: (1) the position of the hypophysis at the posterior area of the hypothalamus (vs. anchored at the midpoint of the hypothalamus) and (2) the presence of lateral subdivision on the lobus facialis (vs. anterolateral positioned).

According to brain gross morphology of $R$. quelen and other examined species of Heptapteridae, a spectrum of variation is notable where at one end are located the genera Rhamdia, Pimelodella and Goeldiella, and on the other all the remaining heptapterids examined herein. While the first three taxa exhibit the telencephalon with a tumid anterior area, along the relative smaller length of the lobus facialis, all other Heptapteridae taxa have 
the telencephalon with thinner anterior area, along the relative longer length of the lobus facialis. The proportional length of the lobus vagi longer than the lobus facialis, the lateral line lobe extending up to the anterior portion of the lobus vagi, and the tectum mesencephali contacting the corpus cerebelli and the general shape of the telencephalon are features present in $R$. quelen, $P$. gracilis and $G$. eques. The widths of the anterior and posterior portions of the telencephalon and their proportional length, and the straight posterior portion of the corpus cerebelli are complementary features present in R. quelen and P. gracilis (Fig. 3 and Table 1). Based on morphological and osteological features, Bockmann (1998) proposed that the genus Goeldiella was sister group of all other heptapterids, however there is no consensus on Rhamdia and Pimelodella position. The phylogenetic relationship at the base of Heptapteridae cladogram remain uncertain (Bockmann \& Miquelarena, 2008; Slobodian \& Bockmann, 2013). Future comprehensive research on Pimelodoidea neuroanatomy may contribute to elucidate those assumptions.

The length of the lobus facialis proportionally greater than length of the lobus vagi, the lateral line lobe extending up to the half-length of the lobus facialis, the tectum mesencephali not contacting the telencephalon, and the shape of the posterior and anterior portions of the telencephalon, are all traits found in Cetopsorhamdia iheringi, Heptapterus mustelinus, Imparfinis mirini, and Phenacorhamdia tenebrosa (Fig. 3; Table 1). This separation agrees with the proposal of Ferraris Jr. (1988) and Bockmann (1994) who included Cetopsorhamdia, Heptapterus, Imparfinis and Phenacorhamdia, in the Nemuroglanis sub-clade, as a distinct group within heptapterids.

The shape, position, and proportional lengths of the brain as a whole, and its different subdivisions, corroborate the relationship hypothesis using external morphology and osteological characters presented by Ferraris Jr. (1988) and Bockmann (1998). These brain characters may allow recognition and resolution of smaller lineages within the family if incorporated to a broader phylogenetic reconstruction of the group.

\section{ACKNOWLEDGEMENTS}

The authors are grateful to J.L. Birindelli and F.C. Jerep (Museu de Zoologia da Universidade Estadual de Londrina - MZUEL) and J. Albert (University of Louisiana) for reading and commenting the manuscript. The authors also thank L.R. Py-Daniel (Instituto Nacional de Pesquisas da Amazônia - INPA and M.C.C. de Pinna (Museu de Zoologia da Universidade de São Paulo MZUSP for specimen donation. And the authors are grateful to the Universidade Estadual de Londrina (UEL) and Conselho Nacional de Desenvolvimento Científico e Tecnológico (CNPq) for financial support. Research funding is provided by CNPq (Proc. 304868/2015-9) and FAPESP (Fundação de Amparo à Pesquisa do Estado de São Paulo, grant \#2014/11397-1 and \#2017/17957-7).

\section{REFERENCES}

Abrahão, V.P. 2013. Anatomia comparada do sistema nervoso central e filogenia da família Pseudopimelodidae (Ostariophysi: Siluriformes). Londrina, PR. Universidade Estadual de Londrina. (Master Dissertation)

Abrahão, V.P. \& Pupo, F.M.R.S. 2014. Técnica de dissecção do neurocrânio de Siluriformes para estudo do encéfalo. Boletim Sociedade Brasileira de Ictiologia, 112: 21-26.

Abrahão, V.P. \& Shibatta, 0.A. 2015. Gross morphology of the brain of Pseudopimelodus bufonius (Valenciennes, 1840) (Siluriformes: Pseudopimelodidae). Neotropical Ichthyology, 13: 255-264.

Abrahão, V.P.; Pupo, F.M. \& Shibatta, O.A. 2018. Comparative brain gross morphology of the Neotropical catfish family Pseudopimelodidae (Osteichthyes, Ostariophysi, Siluriformes), with phylogenetic implications. Zoological Journal of the Linnean Society. D0I

Angrizani, R.C. \& Malabarba, L.R. 2018. Morphology and molecular data reveal the presence of two new species under Rhamdia quelen (Quoy \& Gaimard, 1824) (Siluriformes: Heptapteridae) species complex. Zootaxa, 4388(1): 41-60.

Angulo, A. \& Langeani, F. 2017. Gross brain morphology of the armoured catfish Rineloricaria heteroptera, Isbrücker and Nijssen (1976), (Siluriformes: Loricariidae: Loricariinae): A descriptive and quantitative approach. Journal of Morphology, 278: 1689-1705.

Arratia, G.; Kapoor, B.G.; Chardon, M. \& Diogo, R. 2003. Catfishes. Enfield, Science Publishers.

Atema, J. 1971. Structures and functions of the sense of taste in the catfish (Ictalurus natalis). Brain Behavior and Evolution, 4: 273-294.

Birindelli, J.L.O. \& Shibatta, 0.A. 2011. Morphology of the gas bladder in bumblebee catfishes (Siluriformes, Pseudopimelodidae). Journal of Morphology, 272: 890-896.

Bockmann, F.A. 1994. Description of Mastiglanis asopos, a new pimelodid catfish from northern Brazil, with comments on phylogenetic relationships inside the subfamily Rhamdiinae (Siluriformes: Pimelodidae). Proceeding of the Biological Society of Washington, 107: 760-777.

Bockmann, F.A. 1998. Análise filogenética da família Heptapteridae (Teleostei, Ostariophysi, Siluriformes) e redefinição de seus gêneros. São Paulo, Universidade de São Paulo. (Doctoral Thesis).

Bockmann, F.A. \& Guazzelli, G.M. 2003. Family Heptapteridae (Heptapterids). In: Reis, R.E.; Kullander, S.O. \& Ferraris, C.J. (Eds.). Checklist of the Freshwater Fishes of South and Central America. Porto Alegre, EDIPUCRS. p. 406-431.

Bockmann, F.A. \& Miquelarena, A.M. 2008. Anatomy and phylogenetic relationships of a new catfish species from northeastern Argentina with comments on the phylogenetic relationships of the genus Rhamdella Eigenmann and Eigenmann 1888 (Siluriformes, Heptapteridae). Zootaxa, 1780: 1-54.

Butler, A.B. \& Hodos, W. 2005. Comparative vertebrate neuroanatomy: Evolution and adaptation. New Jersey, Wiley e Sons.

Dingerkus, G. \& Uhler, L.D. 1977. Enzyme clearing of alcian blue stained whole small vertebrates for demonstration of cartilage. Stain Technology, 59: 229-232.

Eastman, J.T. \& Lanno0, M.J. 1995. Diversification of brain morphology in Antarctic notothenioid fishes: basic descriptions and ecological considerations. Journal of Morphology, 223: 47-83.

Eschmeyer, W.N. \& Fong, J.D. 2018. Species by family/subfamily. Available at: http://researcharchive.calacademy.org/research/ichthyology/catalog/ SpeciesByFamily.asp. Access in: 09/05/2018.

Ferraris Jr., C.J. 1988. Relationships of the Neotropical catfish genus Nemuroglanis, with a description of a new species (Osteichthyes: 
Siluriformes: Pimelodidae). Proceedings of the Biological Society of Washington, 101: 509-516.

Ferraris Jr., C.J. 2007. Checklist of catfishes, recent and fóssil (Osteichthyes: Siluriformes), and catalogue of siluriform primary types. Zootaxa, 1418: $1-628$.

Fink, S.V. \& Fink, W.L. 1981. Interrelationships of the ostariophysan fishes (Teleostei). Zoological Journal of the Linnean Society, 72: 297-353.

Gonzalez-Voyer, A. \& Kolm, N. 2010. Sex, ecology and the brain: evolutionary correlates of brain structure volumes in Tanganyikan cichlids. PLoS One, 5(12): e14355.

Hardman, M. 2005. The phylogenetic relationships among non-diplomystid catfishes as inferred from mitochondrial cytochrome $b$ sequences; the search for the ictalurid sister taxon (Otophysi: Siluriformes). Molecular Phylogenetics and Evolution, 37: 700-720.

Herrick, C.L. \& Herrick, C.J. 1891. Contributions to the morphology of the brain of bony fishes. Journal of Comparative Neurology, 1: 211-245.

Howes, G.J. 1983. Problems in catfish anatomy and phylogeny exemplified by the Neotropical Hypophthalmidae (Teleostei: Siluroidei). Bulletin of the British Museum of Natural History (Zoology), 45: 1-39.

Ito, H.; Ishikawa, Y.; Yoshimoto, M. \& Yamamoto, N. 2007. Diversity of brain morphology in teleosts: brain and ecological niche. Brain, Behavior and Evolution, 69: 76-86.

Kleerekoper, H. 1969. Olfaction in fishes. Bloomington, Indiana University Press.

Kotrschal, K. \& Palzenberger, M. 1992. Neuroecology of cyprinids: comparative, quantitative histology reveals diverse brain patterns. In: Balon, E.K.; Wieser, W.; Schiemer, F.; Goldschmidt, A. \& Kotrschal, K. (Eds.). Environmental Biology of Fishes. Dordrecht, Kluwer Academic Publishers. p. 135-152.

Kotrschal, K.; van Staaden, M.J. \& Huber, R. 1998. Fish brains: evolution and environmental relationships. Reviews in Fish Biology and Fisheries, 8: 373-408.

Lanno0, M.J. \& Eastman, J.T. 2000. Nervous and Sensory System Correlates of an Epibenthic Evolutionary Radiation in Antarctic Notothenioid Fishes, Genus Trematomus (Perciformes; Nototheniidae). Journal of Morphology, 79: 67-79.

Lundberg, J.G. 1982. The comparative anatomy of the toothless blindcat, Trogoglanis pattersoni Eigenmann, with a phylogenetic analysis of the ictalurid catfishes. Miscelaneous Publications, University of Michigan, 163: 1-85.

Lundberg, J.G. \& Littmann, M.W. 2003. Pimelodidae (Long-whiskered catfishes). In: Reis, R.E.; Kullander, S.0. \& Ferraris Jr., C.J. (Eds.). Checklist of the freshwater fishes of South and Central America. Porto Alegre, EDIPUCRS. p. 432-446.

Lundberg, J.G. \& McDade, L.A. 1986. On the South American catfish Brachyrhamdia imitator Myers (Siluriformes, Pimelodidae), with phylogenetic evidence for a large intrafamilial lineage. Notulae Naturae, 463: $1-24$

Lundberg, J.G.; Bornbusch, A.H. \& Mago-Leccia, F. 1991. Gladioglanis conquistador $n$. sp. from Ecuador with the diagnoses of the subfamilies
Rhamdiinae Bleeker and Pseudopimelodinae n. subf. (Siluriformes: Pimelodidae). Copeia, 1991: 190-209.

Meek, J. \& Nieuwenhuys, R. 1998. Holosteans and teleosts. In: Nieuwenhuys, R.; Ten Donkelaar, H.J. \& Nicholson, C. (Eds.). The Central Nervous System of Vertebrates. Springer-Verlag, Berlin, 759-937pp.

Pereira, T.N.A. 2014. Anatomia encefálica comparada de Characiformes (Teleostei: Ostariophysi). Ribeirão Preto Faculdade de Filosofia, Ciencias e Letras - Universidade de São Paulo. (Ph.D. Thesis).

Pupo, F.M.R.S. 2011. Anatomia comparada da morfologia externa do sistema nervoso central da família Callichthyidae (Teleostei: Ostariophysi: Siluriformes) e suas implicações filogenéticas. Rio de Janeiro, Universidade Federal do Rio de Janeiro. (Master Dissertation)

Pupo, F.M.R.S. 2015. Anatomia comparada dos encéfalos dos Loricarioidea (Teleostei: Ostariophysi: Siluriformes) e suas implicações filogenéticas. Rio de Janeiro, Universidade Federal do Rio de Janeiro. (Doctoral Thesis)

R Core Team. 2017. R: A language and environment for statistical computing. Vienna, R Foundation for Statistical Computing. URL www.R-project.org.

Rosa, A.C.; Martins, F.O. \& Langeani, F. 2014. Miniaturization in Otothyris Myers, 1927 (Loricariidae: Hypoptopomatinae). Neotropical Ichthyology, 12: $53-60$.

Rosen, D.E. \& Greenwood, P.H. 1970. Origin of the Weberian apparatus and the relationships of the ostariophysan and gonorynchiform fishes. American Museum Novitates, 2428: 1-25.

Shibatta, 0.A. 2003. Family Pseudopimelodidae (Bumblebee catfishes, dwarf marbled catfishes). In: Reis, R.E.; Kullander, S.0. \& Ferraris Jr., C.J. (Eds.). Checklist of the freshwater fishes of South and Central America. Porto Alegre, EDIPUCRS. p. 406-410.

Silfvergrip, A.M. 1996. A systematic revision of the Neotropical catfish genus Rhamdia (Teleostei, Pimelodidae). Stockolm, University of Stockholm.

Slobodian, V. \& Bockmann, F.A. 2013. A new Brachyrhamdia (Siluriformes: Heptapteridae) from Rio Japurá basin, Brazil, with comments on its phylogenetic affinities, biogeography and mimicry in the genus. Zootaxa, 3717(1): 1-22.

Sullivan, J.P.; Lundberg, J.G. \& Hardman, M. 2006. A phylogenetic analysis of the major groups of catfishes (Teleostei: Siluriformes) using rag 1 and rag2 nuclear gene sequences. Molecular Phylogenetics and Evolution, 40: 636-662.

Sullivan, J.P.; Muriel-Cunha, J. \& Lundberg, J.G. 2013. Phylogenetic relationships and molecular dating of the major groups of catfishes of the Neotropical superfamily Pimelodoidea (Teleostei, Siluriformes). Proceedings of the Academy of Natural Sciences of Philadelphia, 162: $89-110$.

Tong, S.L. \& Finger, T.E. 1983. Central organization of the electrosensory lateral line system in bullhead catfish Ictalurus nebulosus. Journal of Comparative Neurology, 217: 1-16.

van Staaden, M.; Huber, R.; Kaufman, L. \& Liem, K. 1995. Brain evolution in cichlids of the African Great Lakes: brain and body size, general patterns and evolutionary trends. Zoology, 98: 165-78. 